\title{
Problems of women farmers in agriculture
}

\author{
MITHILESH VERMA ${ }^{1}$, SWATI SINGH* AND VIDESH KUMAR VERMA ${ }^{2}$ \\ ${ }^{1}$ Department of Extension Education and Communication Management, College of Home Science, \\ C.S.A. University of Agriculture and Technology, KANPUR (U.P.) INDIA \\ ${ }^{2}$ Department of Agronomy, C.S.A. University of Agriculture and Technology, KANPUR (U.P.) INDIA
}

\begin{abstract}
The present study entitled "Problems of women in Agriculture" was carried in two distances Hamirpur and Kanpur to assess the problems of women farmers. Thus, selected total 120 respondents and 60 respondents were selected from each district. Out of out of total respondents 44.2 per cent respondents belonged to 50 years and above age group. 40.8 per cent respondents were educated up to primary level. 85.0 per cent respondents were belonged to Hindu religion, 45.0 per cent belonged to OBC group, 50.8 per cent respondents were doing agriculture. 59.2 per cent respondents have lived in pukka house. 63.3 per cent has nuclear family in which 50.8 per cent respondents have belonged to medium family size. 34.27 per cent respondents belonged to those families whose annual income was between 3 lacks to 4.5 lacks and above, 57.5 per cent respondents having 2.5 to 5 acres (marginal farmers). After studying women have faced many problems higher number of women have faced seasonal problems, women faced dehydration problem in summer season with 3.82 mean value, fungal infection in rainy season with 3.9 mean score value and common cold in winter season with 3.77 mean score value. Women found health hazards by pesticide with 3.89 mean score. Some women have instant allergic reaction with 3.7 mean score. Cutting tools create problem many a time with 2.67 mean score. Women were faced back pain with 3.7 mean score. Women were faced snake and insect bites with 3.44 mean score. Many women faced problem of irritation of the eyes with 3.75 mean score. And many have bacterial infection problem with 3.58 mean score value. And most of the women have being affected by some health problems while workings in agriculture with 4.00 mean score value. Further, studying causes of problems, it was found that causes of seasonal problems that high temperature is the most affecting causes of summer with 0.95 mean score, high humidity climate causes of rainy season problem with 1.87 mean score and cold winds cause to of winter season problem with 1.83 mean score. Many women have faced various physical problems due to prolonged mono-static body gesture with 1.76 mean score. And diseases by agrochemicals are very minute molecules and they can enter very easily in respiratory or 2 digestive system through water, food, respiration etc. so those problems of infected water due to agro-chemicals with 1.59 mean score. Biological agents and vector problem also having a vital effect on human health due to insect is high with 2.52 mean score. Improper use of sharp tools and farm machineries causes injuries with 1.65 mean score value. Fumes as largest causes of respiratory system problem with 1.88 mean score and straw and dust as major causes of irritation of the eyes with 1.84 mean score value. And most of the women farmers faced many health problems due to malnutrition with 2.65 mean score value. From the study it was concluded that mostly women farmers faced various problems while working in agriculture.
\end{abstract}

KeY Words : Problems, Women farmers, Agriculture

View Point Article : Verma, Mithilesh, Singh, Swati and Verma, Videsh Kumar (2015). Problems of women farmers in agriculture. Internat. J. Home Sci. Extn. \& Comm. Manage., 2 (2): 95-99.

Article History : Received : 26.02.2015; Revised : 24.05.2015; Accepted : 23.06.2015 